OPEN ACCESS

Edited by:

Pierrette Gaudreau, Université de Montréal, Canada

Reviewed by:

Roger Godbout, Université de Montréal, Canada

Alessandro Martorana, University of Rome Tor Vergata, Italy

*Correspondence:

Mounir Chennaoui mounirchennaoui@gmail.com

Specialty section:

This article was submitted to Neuroendocrine Science,

a section of the journal

Frontiers in Neuroscience

Received: 18 October 2016 Accepted: 11 April 2017

Published: 02 May 2017

Citation:

Chennaoui M, Arnal PJ, Drogou C,

Leger $D$, Sauvet $F$ and Gomez-Merino D (2017) Leukocyte

Expression of Type 1 and Type 2

Purinergic Receptors and

Pro-Inflammatory Cytokines during

Total Sleep Deprivation and/or Sleep

Extension in Healthy Subjects.

Front. Neurosci. 11:240

doi: 10.3389/fnins.2017.00240

\section{Leukocyte Expression of Type 1 and Type 2 Purinergic Receptors and Pro-Inflammatory Cytokines during Total Sleep Deprivation and/or Sleep Extension in Healthy Subjects}

\author{
Mounir Chennaoui 1, 2*, Pierrick J. Arnal ${ }^{1,2}$, Catherine Drogou ${ }^{1,2}$, Damien Leger ${ }^{2,3}$, \\ Fabien Sauvet ${ }^{1,2}$ and Danielle Gomez-Merino ${ }^{1,2}$ \\ ${ }^{1}$ Fatigue and Vigilance team, Neuroscience and Operational Constraints Department, French Armed Forces Biomedical \\ Research Institute (IRBA), Brétigny-sur-Orge, France, ${ }^{2}$ VIFASOM team (EA 7330), Paris Desacrtes University, Sorbonne Paris \\ Cité, Hôtel Dieu, Paris, France, ${ }^{3}$ Centre du Sommeil et de la Vigilance, Hôtel Dieu, Assistance publique - Hôpitaux de Paris, \\ Paris, France
}

The purinergic type $\mathrm{P} 1$ (adenosine $\mathrm{A}_{1}$ and $\mathrm{A}_{2 \mathrm{~A}}$ ) receptors and the type P2 (X7) receptor have been suggested to mediate physiological effects of adenosine and adenosine triphosphate on sleep. We aimed to determine gene expression of $A_{1} R$ (receptor), $A_{2 A} R$, and $\mathrm{P} 2 \mathrm{RX} \mathrm{X}_{7}$ in leukocytes of healthy subjects during total sleep deprivation followed by sleep recovery. Expression of the pro-inflammatory cytokines IL-1 $\beta$ and TNF- $\alpha$ were also determined as they have been characterized as sleep regulatory substances, via $\mathrm{P}_{2 \mathrm{RX}}$ activation. Blood sampling was performed on 14 young men (aged $31.9 \pm 3.9$ ) at baseline (B), after $24 \mathrm{~h}$ of sleep deprivation ( $24 \mathrm{~h}-S D$ ), and after one night of sleep recovery (R). We compared gene expression levels after six nights of habitual (22.30-07.00) or extended (21.00-07.00) bedtimes. Using quantitative real-time PCR, the amount of mRNA for $A_{1} R, A_{2 A} R, P 2 R X_{7}, T N F-\alpha$, and IL-1 $\beta$ was analyzed. After 24 h-SD compared to $B$, whatever prior sleep condition, a significant increase of $A_{2 A} R$ expression was observed that returned to basal level after sleep recovery [day main effect, $F_{(2,26)}=$ 10.8, $p<0.001$ ]. In both sleep condition, a day main effect on $\mathrm{P}_{2} \mathrm{RX} \mathrm{X}_{7} \mathrm{mRNA}$ was observed $\left[F_{(2,26)}=6.7, p=0.005\right]$ with significant increases after $\mathrm{R}$ compared with $24 \mathrm{~h}-S D$. TNF- $\alpha$ and IL-1 $\beta$ expressions were not significantly altered. Before $24 \mathrm{~h}-S D$ (baseline), the $A_{2 A} R$ expression was negatively correlated with the latency of stage 3 sleep during the previous night, while that of the $A_{1} R$ positively. This was not observed after sleep recovery following $24 \mathrm{~h}-S D$. This is the first study showing increased $A_{2 A} R$ and not $A_{1}$ gene expression after 24 h-SD in leukocytes of healthy subjects, and this even if bedtime was initially increased by $1.5 \mathrm{~h}$ per night for six nights. In conclusion, prolonged wakefulness induced an up-regulation of the A2A receptor gene expression in leukocytes from healthy subjects. Significant correlations between baseline expression of $A_{1}$ and $A_{2 A}$ receptors in peripheral cells and stage 3 sleep suggested their involvement in mediating the effects of adenosine on sleep.

Keywords: sleep deprivation, adenosine and purinergic receptors, gene expression, leukocytes 


\section{INTRODUCTION}

Adenosine is a metabolic intermediate of the energy-rich molecule adenosine-tri-phosphate (ATP) and a pleiotropic bioactive molecule with potent neuromodulatory properties because of its ability to cross the blood-brain barrier; it was proposed as a signaling molecule between the periphery and the brain (Chiu and Freund, 2014). Adenosine receptors are ubiquitously distributed throughout brain, heart, immune, and inflammatory cells and many other tissues. In the central nervous system (CNS), adenosine plays important functions such as modulation of neurotransmitter release, synaptic plasticity, and neuroprotection in ischemic, hypoxic, and oxidative stress events (Rodrigues et al., 2015). Numerous studies indicate that endogenous adenosine is a candidate for the sleep regulation and it induced sleep after prolonged wakefulness (Basheer et al., 2004). Moreover, adenosine interplays with several neurotransmitters that regulate sleep (Weber and Dan, 2016). Adenosine promotes sleep, at least in part, by inhibiting wakefulness-promoting neurons localized to the basal forebrain, lateral hypothalamus, and tuberomammillary nucleus of the posterior hypothalamus. There are two forms of sleep, nonrapid eye movement (NREM) sleep and rapid eye movement (REM) sleep. In humans, NREMS occupies about $80 \%$ and REMS about $20 \%$ of sleep time. These two stages alternate with each other with about a 90-100 min periodicity, with more NREM sleep occurring during the first half and more REM sleep occurring during the second half of the night (Krueger et al., 2008). The formation of adenosine in the brain changes in activity-dependent manner and is linked to the intracellular depletion of ATP (Krueger et al., 2013). The sleep inducing effects of extracellular adenosine are mediated through only two of the four adenosine receptor subtypes $\left(A_{1}, A_{2 A}, A_{2 B}\right.$, and $\left.A_{3}\right)$ : the inhibitory $G$ protein-coupled adenosine $A 1$ receptor $\left(A_{1} R\right)$ and the excitatory $G$ protein-coupled adenosine $A 2$ receptor $\left(A_{2} R\right)$ (Landolt et al., 2012). This author has suggested that both $A_{1}$ and $A_{2 A}$ receptor subtypes probably mediate the effects of adenosine on vigilance and sleep, and these effects appear to be brain regions and receptor-dependent. Adenosine seems to promote sleep by simultaneously activating sleep-active neurons through $\mathrm{A}_{2 \mathrm{~A}} \mathrm{R}$ and suppressing wake-active neurons through $A_{1} R$ (Watson et al., 2010). The $A_{1} R$ activation in histaminergic neurons of the tuberomammillary nucleus increases NREM sleep (Oishi et al., 2008) while the activation of $\mathrm{A}_{2 \mathrm{~A}} \mathrm{R}$ in the pontine reticular formation increases acetylcholine release and NREM sleep (Coleman et al., 2006). Extracellular adenosine levels in basal forebrain and frontal cortex increased during 6 or $11 \mathrm{~h}$ of sleep deprivation but not in four other subcortical structures, and then decreased during recovery sleep (Porkka-Heiskanen et al., 2000; Kalinchuk et al., 2011). After 5 days of sleep restriction, $A_{1} R$ mRNA levels and density were increased in the basal forebrain region and several brain regions respectively, whereas $A_{2 A} R$ mRNA levels and density were reduced in the frontal cortex and olfactory tubercle (Kim et al., 2012, 2015). Total sleep deprivation also upregulates $\mathrm{A}_{1} \mathrm{R}$ mRNA levels in the rat basal forebrain and increased its density in cortical and subcortical brain regions (Basheer et al., 2007; Elmenhorst et al., 2009). In the human brain, a single night of total sleep deprivation leads to a significant increase of the $A_{1} R$ binding (Elmenhorst et al., 2007). The same research group recently showed that variation of $A_{1} R$ regional availability is associated with the $A_{1} R$ and $A_{2 A} R$ gene polymorphisms in the human brain (Hohoff et al., 2014). In addition, a role for the $A_{2 A} R$ gene polymorphism has been particularly related to be an important determinant of psychomotor vigilance in rested and in acute and chronic sleep-deprived state (Bodenmann et al., 2012; Rupp et al., 2013). Indeed several studies have previously shown that sleep deprivation or restriction is associated with increased daytime sleepiness, decreased cognitive and physical performance, increased inflammatory markers (pro-inflammatory cytokines IL- $1 \beta$ and TNF- $\alpha$ ) and hormonal/metabolic disturbances (Rupp et al., 2009; Chennaoui et al., 2011, 2015; Arnal et al., 2015, 2016; Irwin et al., 2015; Sauvet et al., 2015).

During wakefulness, the increase of extracellular ATP in brain may either be hydrolyzed to adenosine or activate purine type 2 receptors such as $\mathrm{P} 2 \mathrm{X}_{7}$ receptors $\left(\mathrm{P} 2 \mathrm{RX}_{7}\right)$ that affect sleep directly or indirectly through cytokines release or other sleep regulatory substances (Krueger, 2008; Krueger et al., 2010). The gene expression of $\mathrm{P} 2 \mathrm{RX}_{7}$ has been evidenced in immune cells (North, 2002) and one study has shown increased expression in peripheral monocytes after $24 \mathrm{~h}$ of sleep deprivation in healthy young volunteers (Backlund et al., 2012).

The $\mathrm{A}_{1}$ and $\mathrm{A}_{2 \mathrm{~A}}$ and $\mathrm{P}_{2} \mathrm{X}_{7}$ receptors are expressed in human leukocytes and were reported to play a central role in mechanisms of inflammation associated to various neurological pathologies (Fortin et al., 2006; Varani et al., 2010; Chiu and Freund, 2014; Casati et al., 2016; Krügel, 2016). Moreover, leukocytes have been proposed as a useful peripheral model to study inflammatory processes in the CNS (Sullivan et al., 2006; Varani et al., 2010; Light et al., 2012).

In this study, we determined for the first time whether advancing bedtime by $1.5 \mathrm{~h}$ per night over six nights (i.e., going to bed at 21.00 vs. 22.30 and getting up at 07.00 in both conditions) influences $A_{1} R, A_{2 A} R$, and $P 2 R X_{7}$ mRNA levels in leukocytes of healthy subjects during total sleep deprivation (TSD) followed by one night of sleep recovery. The gene expressions of the pro-inflammatory somnogenic cytokines IL- $1 \beta$ and TNF- $\alpha$ were also determined. We hypothesized that longer bedtime for sleep and/or sleep deprivation may altered peripheral purine type 1 and type 2 receptors.

\section{METHODS}

\section{Subjects}

Fourteen healthy men, aged $31.4 \pm 3.9$ years (mean $\pm S D$ ), with a body mass index (BMI) of $24.0 \pm 2.0 \mathrm{~kg} / \mathrm{m}^{2}$ were included in the study after providing their written informed consent. The ethics committee of the Hotel Dieu Hospital-Ile de France 1 (Paris) and the French National Agency for the Safety of Medicines and Health Products (ANSM) approved the protocol ( ${ }^{\circ}$ ID RCB: 2013-A01403-42), which was conducted according to the principles expressed in the Declaration of Helsinki of 1975 as revised in 2001. All subjects underwent a detailed medical history and examination including an electrocardiogram at rest, 
performed by a physician. Subjects were excluded if they were shift-workers, smokers, consumers of more than three alcoholic beverages weekly and of more than $400 \mathrm{mg}$ of caffeine per day (i.e., about eight caffeinated sodas or 3-4 cups of coffee), with a $\mathrm{BMI}>28 \mathrm{~kg} / \mathrm{m} 2$, and taking medication. Exclusion criteria also included: subjects with excessive daytime somnolence (Epworth Sleepiness Scales > 11; Johns, 1961), sleep complaints (Pittsburgh Sleep Quality Index > 5; Buysse et al., 1989), who could not be considered as an intermediate chronotype or moderately morning type on the Horne and Ostberg questionnaire $(<42$ and $>69$; Horne and Ostberg, 1976), or who scored $\geq 13$ on the Beck Depression Inventory (Beck et al., 1961), or $\geq 13$ on the Hospital Anxiety and Depression Scale (HADS; Zigmond and Snaith, 1983).

\section{Protocol}

The TSD experimental protocol took place at the Hôtel Dieu Hospital (Paris, France) where subjects were housed individually in a temperature-controlled bedroom $\left(24 \pm 1^{\circ} \mathrm{C}\right)$. The total sleep deprivation started at 07:00 after one night of sleep in the laboratory and finished the day after at 21:00 (i.e., $38 \mathrm{~h}$ of continuous awakening). After one night of sleep recovery, subjects left the laboratory in the afternoon. During the TSD protocol, the sleep of subjects was continuously monitored by an ultra-miniaturized polysomnography PSG in order to limit patient discomfort (Actiwave, CamNtech LtD, Cambridge, UK). Laboratory illumination was maintained at 150-200 lux during the entire period of sleep loss. When not engaged in any specific testing or meal, subjects were allowed to read, watch videos, or play games, or converse with the staff or visitors. Subjects were prohibited from exercise, caffeine, tobacco, alcohol, and other psychoactive substances $24 \mathrm{~h}$ before and during the study. Meals and caloric intake were standardized for all subjects (2700 $\mathrm{kcal} /$ day). Water was allowed ad libitum.

Blood samples were collected at 07:00 in fasting state, subjects lying down on bed. They were collected at baseline (B), after $24 \mathrm{~h}$ of sleep deprivation ( $24 \mathrm{~h}-S D)$, and after the recovery sleep (R). For mRNA quantification, blood was collected in PAXgene blood RNA tubes (PreAnalytix, GmbH, 8634 Hombrechtikon, $\mathrm{CH}$ ), and tubes were stored at $-80^{\circ} \mathrm{C}$.

During six nights before the TSD protocol, subjects were under two counterbalanced sleep conditions (cross-over design): habitual sleep condition (HAB) (22.30-07.00 h) or extended sleep condition (EXT) (21.00-07.00 h). The sleep was recorded by an ultra-miniaturized PSG. The washout period between the two experimental conditions was 6 weeks. In the $21.00-07.00 \mathrm{~h}$ sleep condition, subjects were allowed to read a little if needed to sleep, although cell phone/tablet use was prohibited, and they were instructed to turn off lights for sleeping and not to take any naps during the day. In addition, the use of low and indirect lighting was recommended before going to bed. In both sleep conditions, volunteers maintained a wake-up time of 07:00 to accustom them to the waking time of 07:00 used during the TSD protocol in laboratory. Volunteers were allowed to maintain their usual lifestyles but needed to return the PSG equipment to the laboratory every morning. The first five nights were conducted at home and the sixth night was at the laboratory under HAB or
EXT sleep condition; for the night of sleep recovery subjects went to bed at 21:00 and get up at 07:00 (Figure 1).

\section{Measurements \\ Night-Time Sleep Assessment}

An ultra-miniaturized PSG (Actiwave, CamNtech LtD, Cambridge, UK) provides continuous monitoring for six EEG (F3, C3, O1 and F4, C4, O2), two electrocardiograms and two electrooculograms (outer canthus of each eye), and two electromyograms (chin). Contralateral mastoid leads served as references for all unipolar measurements (electroencephalograms and electrooculograms). Bio-electrical EEG signals were digitized at a sampling frequency of $200 \mathrm{~Hz}$ with a 16 bit quantization between -500 and $500 \mu \mathrm{V}$, within a bandwidth of $0-48 \mathrm{~Hz}$. PSG data were scored by two trained research technicians in accordance with the American academy of sleep medicine criteria (Iber et al., 2007) using Somnologica software (TM, Medcare ${ }^{\circledR}$, Reykjavik, Iceland). Duration of the different sleep stages [sleep stages 1, 2, 3, and rapid eye movement (REM) sleep], latencies of stage 3 and REM sleep, wakefulness after sleep onset (WASO), sleep efficiency, and sleep latency were determined.

\section{Quantification of Blood Cells}

Leukocyte counts and subsets were determined on the automated hematology system XE 5000 (SYSMEX Mundelein, IL 60060, US).

\section{Gene Expression Analysis}

\section{$m R N A$ isolation and reverse transcription}

RNA from blood collected in PAXgene RNA tubes was extracted according to the manufacturer's instructions. RNA quantity was measured with a Nanodrop spectrophotometer ND-1000 (Thermo Scientific). RNA was immediately stored at $-80^{\circ} \mathrm{C}$. Reverse transcription was performed using the RT2 HT First Strand kit (Qiagen). The reaction was carried out using $0.5 \mu \mathrm{g}$ of RNA. The cDNA was stored at $-80^{\circ} \mathrm{C}$ until use.

\section{Real time PCR}

PCR was carried out with 96-well plate's customed RT2 Profiler Arrays in combination with RT2 SYBR Green mastermix (SA Biosciences Qiagen, Venlo, Netherlands) using $1 \mu \mathrm{L}$ of cDNA in a final volume of $25 \mu \mathrm{L}$. The cDNA sequences (human) for TNF- $\alpha$, IL- $1 \beta$, and $\mathrm{P} 2 \mathrm{RX}_{7}, \mathrm{~A}_{1} \mathrm{R}$ and $\mathrm{A}_{2 \mathrm{~A}} \mathrm{R}$ were from GenBank (accession numbers NM_000594, NM_000576, NM_002562, NM_000674, and NM_000675, respectively), as were those of the three reference genes HMBS, H6PD, and HPRT1 (accession numbers NM_000190, NM_004285, and NM_000194). Reactions were performed on a LightCycler 480 (96-well-block) and the crossing point values were calculated using LightCycler Software v3.5 (Roche Applied Science, Mannheim, Germany). Amplification specificity was checked using melting curve analysis following the manufacturer's instructions. The genomic DNA control (GDC), the reverse-transcription control (RTC) and the positive PCR control (PPC) were tested for each sample for genomic DNA contamination, reverse transcription efficiency, and the polymerase chain reaction, respectively. The normalization was performed by geometric averaging of the three housekeeping 


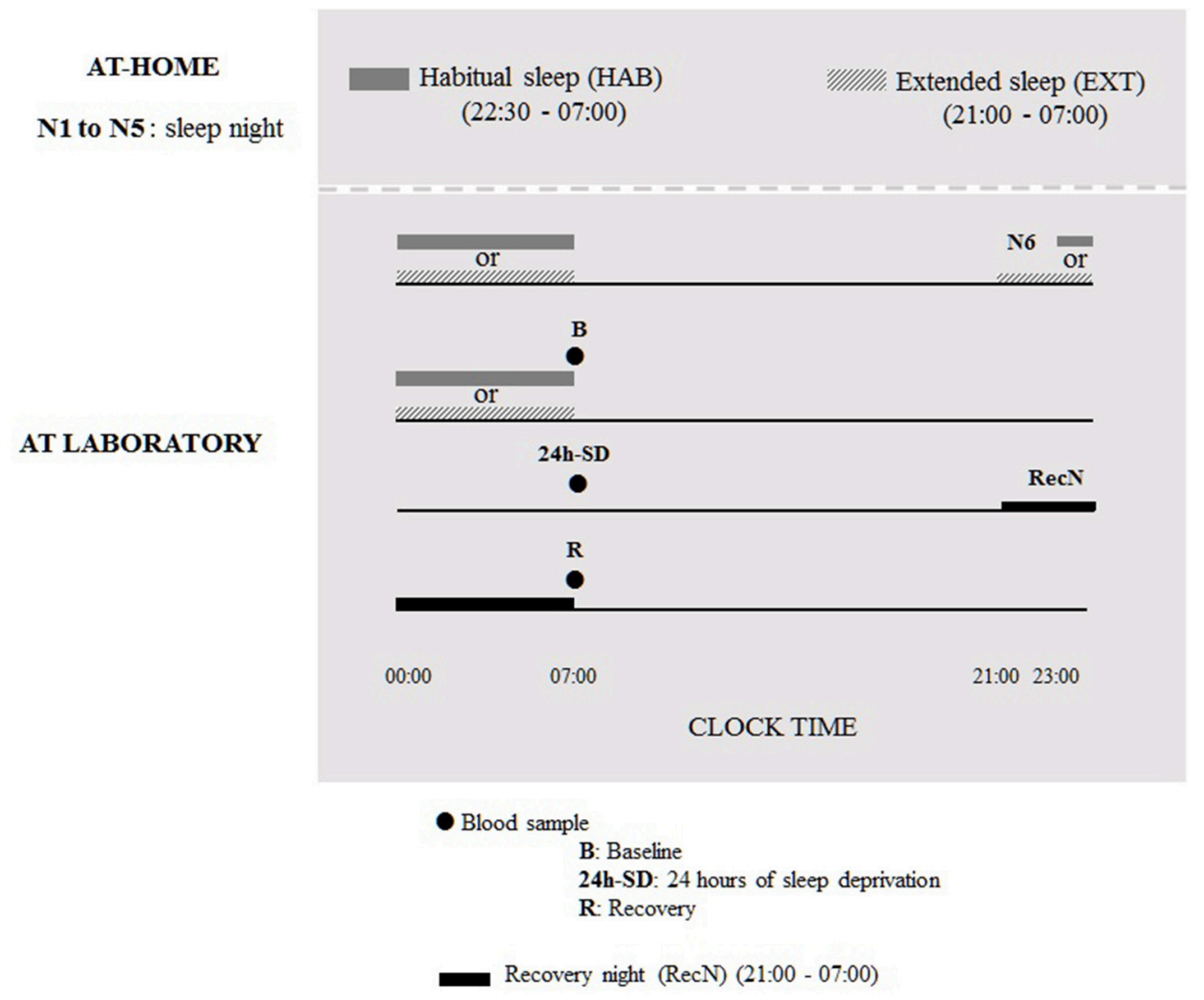

FIGURE 1 | Design of experimental protocol.

genes (HMBS, H6PD, and HPRT1). The mean normalized mRNA (i.e., mRNA/mRNA $\left.\mathrm{m}_{\text {housekeeping genes }}\right) \pm \mathrm{SEM}$ values are presented.

\section{Statistics}

All data in text and figures are presented as mean \pm standard error of the mean (SEM). Statistical analyses were performed using Statistica 6.0, StatSoft Inc., Maisons-Alfort, France.

Two-way repeated measures ANOVAs (condition $\times$ night) were conducted on sleep parameters. Two-way ANOVAs measures (sleep condition $\times$ day) were conducted on blood parameters. When the ANOVA revealed significant interactions or main effect, a Tukey post-hoc test was used to identify differences. Pearson's test was employed for the correlation analysis. Statistical significance was set at $p<0.05$.

\section{RESULTS}

\section{Blood Cells Count and Gene Expression Analysis}

In the two sleep conditions (22.30-07.00 and 21.00-07.00) no significant difference (sleep condition and day main effects) in leukocyte counts was found (B, 24 h-SD, $R: 6.9 \pm 1.6,7.2 \pm$ 1.5 , and $7.4 \pm 1.5$ for $\mathrm{HAB}$ and $7.3 \pm 2.1,7.6 \pm 1.8,7.2 \pm 1.9$ for EXT, expressed as cells $\times 10^{9}$ ). Lymphocyte, monocyte and neutrophil counts were not significantly changed either during sleep deprivation or between sleep conditions (data not shown).

Figure 2 shows amount of mRNA encoding $A_{2 A} R, A_{1} R$, $\mathrm{P}_{2} \mathrm{RX}_{7}, \mathrm{IL}-1 \beta$, and TNF- $\alpha$. In the two sleep conditions (HAB and EXT), a significant increase in amount of mRNA encoding $\mathrm{A}_{2 \mathrm{~A}} \mathrm{R}$ was observed after $24 \mathrm{~h}-\mathrm{SD}$ that returned to their basal concentrations after recovery sleep [day main effect, $F_{(2,26)}=$ 10.8, $p<0.001]$.

In the two sleep conditions ( $\mathrm{HAB}$ and EXT), $\mathrm{P} 2 \mathrm{RX}_{7} \mathrm{mRNA}$ expression levels increased significantly after the night of sleep recovery compared to $24 \mathrm{~h}-S D$ [day main effect, $F_{(2,26)}=6.7, p$ $=0.005$.

No significant difference (sleep condition and day main effects) in gene expression of $\mathrm{A}_{1} \mathrm{R}\left[F_{(1,13)}=0.11, p=0.74 ; F_{(2,26)}\right.$ $=1.69, p=0.20], \mathrm{TNF} \alpha\left[F_{(1,13)}=1.70, p=0.21 ; F_{(2,26)}=0.57\right.$, $p=0.57]$, and IL- $1 \beta\left[F_{(1,13)}=0.95, p=0.35 ; F_{(2,26)}=2.53, p=\right.$ 0.09 ] was found.

The correlation analysis showed that mRNA levels of $A_{2 A} R$ and TNF- $\alpha$ were significantly and positively correlated at B, 24 h$S D$ and $\mathrm{R}$ after considering all subjects in the two sleep conditions ( $r=0.564, r=0.425$, and $r=0.503, p<0.05$, respectively).

\section{Night-Time Sleep Assessment}

Table 1 summarizes the sleep parameters during the sixth night before TSD (N6) and the night of sleep recovery $(\mathrm{RecN})$ under 

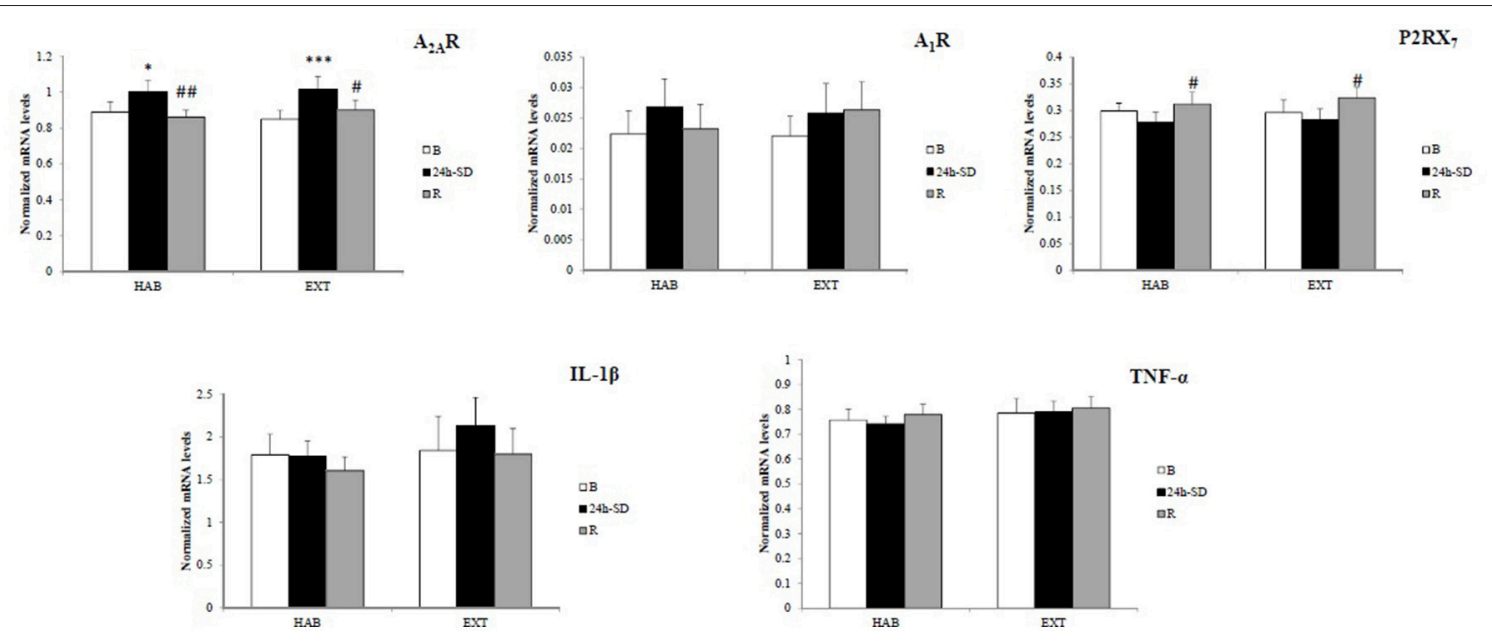

FIGURE 2 | Normalized mRNA levels of adenosine $\left(A_{2 A}\right.$ and $\left.A_{1}\right)$ and type 2 purinergic (P2X $)$ receptors, and IL-1 $\beta$ and TNF- $\alpha$ in leukocytes of healthy men in habitual (HAB) and extended (EXT) sleep conditions (respectively, 22.30-07.00 and 21.00-07.00 bedtimes), at baseline (B), after 24 h of sleep deprivation (24 h-SD) and after one night of sleep recovery (R). $N=14$. ${ }^{\star}$ Significantly different from baseline $(\mathrm{B}),{ }^{\star} p<0.05,{ }^{* \star \star} p<0.001 . \#$ Significantly different from 24-SD, \#p < 0.05 and \#\#p $<0.01$.

HAB or EXT sleep conditions. Total sleep time and sleep stages 1,2 , and REM were significantly longer in the EXT compared to HAB sleep condition, while no difference was observed for sleep stage 3, stage 3 and REM latencies, sleep efficiency, sleep latency, and WASO. There was no difference between sleep conditions for any of the PSG parameters during the RecN.

In the HAB sleep condition, total sleep time, sleep stage 1, stage 3 and stage 3 latency, sleep efficiency and latency, and WASO were higher after RecN compared to N6. In the EXT sleep condition, sleep stage 1 , stage 3 and stage 3 latency, sleep efficiency and latency, and WASO were higher after RecN compared to N6.

We performed the correlation analysis between $A_{1} R, A_{2 A} R$, and TNF- $\alpha$ mRNA levels at baseline (i.e., B) and the sleep characteristics of the N6 night. The analysis was also performed between mRNA levels after sleep recovery (i.e., R) and the sleep characteristics of the RecN. At baseline, the latency of stage 3 sleep correlated with $\mathrm{A}_{1}$ and $\mathrm{A}_{2 \mathrm{~A}} \mathrm{R}$ gene expression in an opposite way. In the EXT condition, we find negative correlation with $A_{2 A} R$ mRNA levels, and positive correlation with $A_{1} R$ mRNA levels in the $\mathrm{HAB}$ condition. At recovery, the only one significant negative correlation was between the TNF- $\alpha$ mRNA and the latency of stage 3 sleep in the EXT sleep condition (Table 2). When data of HAB and EXT sleep conditions were pooled $(N=$ 52), Pearson rank correlation coefficients between $A_{2 A} R$ and $A_{1} R$ expression and latency of stage 3 sleep were respectively: -0.406 and $0.435, p<0.05$.

\section{DISCUSSION}

Our present study shows that $\mathrm{A}_{2 \mathrm{~A}} \mathrm{R}$ mRNA levels in leukocytes of healthy subjects increase after $24 \mathrm{~h}-S D$ and recover basal levels after a night of sleep recovery, while $A_{1} R$ has not changed, and this in two initial sleep conditions (21.00-07.00 and 22.3007.00 bedtimes). The gene expression of $\mathrm{P}_{2} \mathrm{RX}_{7}$ is increased after the night of sleep recovery compared to $24 \mathrm{~h}-S D$ in both sleep conditions, while IL- $1 \beta$ and TNF- $\alpha$ were not changed after $24 \mathrm{~h}-\mathrm{SD}$ and sleep recovery.

In this study, we analyzed gene expression in leukocytes because it may be a useful surrogate for gene expression in the CNS, when relevant genes are expressed in blood and brain (Chennaoui et al., 2005; Sullivan et al., 2006). The leukocyte gene expression of $\mathrm{A}_{1}$ and/or $\mathrm{A}_{2 \mathrm{~A}}$ receptors, as that of $\mathrm{P} 2 \mathrm{X}_{7}$ receptor and the pro-inflammatory cytokines TNF- $\alpha$ and IL- $1 \beta$ was demonstrated altered in various neurological pathologies or in the stress conditions of total sleep deprivation and sleep restriction; (Varani et al., 2010; Backlund et al., 2012; Chennaoui et al., 2014; Sauvet et al., 2015; Casati et al., 2016). For HurtadoAlvarado et al. (2016), sleep loss may induce blood-brain barrier disruption through a systemic low-grade inflammation characterized by the release of several molecules including cytokines, adenosine, and hormones.

Sleep mechanisms are complex and multiple brain areas have been implicated in controlling the switch between wakefulness and the general state of sleep. Sleep-active neurons in the preoptic hypothalamus area inhibits wake-active neurons in the lateral hypothalamus (histamine neurons) and in the brainstem (serotonin and norepinephrine neurons). Sleep-active GABAergic neurons in the preoptic hypothalamus are inhibited by norepinephrine, acetylcholine and a subgroup by serotonin (Weber and Dan, 2016). In addition, adenosine, that accumulates during wakefulness under sleep pressure, has been extensively studied as a somnogen. Adenosine regulates also multiple physiological functions such as arousal, neuroprotection, learning and memory, cerebral blood circulation as well as pathological phenomena such as epilepsy. It is produced primarily from the metabolism of ATP and exerts pleiotropic 
TABLE 1 | Sleep parameters during the night before total sleep deprivation (N6) and the night of sleep recovery (RecN) in habitual and extended sleep condition.

\begin{tabular}{|c|c|c|c|c|c|c|}
\hline & & \multirow[t]{2}{*}{ N6 } & \multirow[t]{2}{*}{$\operatorname{RecN}$} & \multicolumn{3}{|c|}{ ANOVA } \\
\hline & & & & $\begin{array}{l}\text { Sleep condition } \\
F_{(1,12)}\end{array}$ & $\begin{array}{c}\text { Night } \\
F_{(1,12)}\end{array}$ & $\begin{array}{c}\text { Interaction } \\
F_{(1,12)}\end{array}$ \\
\hline \multirow[t]{2}{*}{ Total sleep time (min) } & HAB & $411 \pm 8$ & $543 \pm 6^{\star \star \star}$ & $51^{\$ \$ \$}$ & $173.7^{\$ \$ \$}$ & $43.5^{\$ \$ \$}$ \\
\hline & EXT & $513 \pm 10^{\# \# \#}$ & $545 \pm 3$ & & & \\
\hline \multirow[t]{2}{*}{ Stage 1 (min) } & $\mathrm{HAB}$ & $20 \pm 2$ & $7 \pm 1^{* * \star}$ & $14.3^{\$ \$}$ & $47.4^{\$ \$ \$}$ & 4.20 \\
\hline & EXT & $34 \pm 4^{\# \# \#}$ & $9 \pm 2^{\star \star \star}$ & & & \\
\hline \multirow[t]{2}{*}{ Stage 2 (min) } & HAB & $175 \pm 9$ & $193 \pm 9$ & $20.3^{\$ \$ \$}$ & 0.20 & $6.8^{\$ \$}$ \\
\hline & EXT & $222 \pm 11^{\# \# \#}$ & $195 \pm 11$ & & & \\
\hline \multirow[t]{2}{*}{ Stage 3 (min) } & HAB & $132 \pm 7$ & $231 \pm 13^{\star \star \star}$ & 0.60 & $188.4^{\$ \$ \$}$ & 1.80 \\
\hline & EXT & $149 \pm 12$ & $222 \pm 10^{\star \star \star}$ & & & \\
\hline \multirow[t]{2}{*}{ Stage 3 latency } & $\mathrm{HAB}$ & $38 \pm 5$ & $12 \pm 2^{\star \star}$ & 3.40 & $57.8^{\$ \$ \$}$ & 0.01 \\
\hline & EXT & $45 \pm 5$ & $20 \pm 4^{\star *}$ & & & \\
\hline \multirow[t]{2}{*}{ REM (min) } & $\mathrm{HAB}$ & $84 \pm 6$ & $112 \pm 9$ & $9.6^{\$ \$}$ & $14.2^{\$ \$}$ & 1.10 \\
\hline & EXT & $109 \pm 7^{\#}$ & $119 \pm 4$ & & & \\
\hline \multirow[t]{2}{*}{ REM latency } & $\mathrm{HAB}$ & $129 \pm 9$ & $162 \pm 22$ & 0.22 & 0.71 & 2.41 \\
\hline & EXT & $159 \pm 14$ & $144 \pm 14$ & & & \\
\hline \multirow[t]{2}{*}{ Sleep efficiency (\%) } & $\mathrm{HAB}$ & $85 \pm 2$ & $94 \pm 1^{\star \star \star}$ & 0.10 & $47.3^{\$ \$ \$}$ & 0.10 \\
\hline & EXT & $85 \pm 2$ & $95 \pm 1^{\star * *}$ & & & \\
\hline \multirow[t]{2}{*}{ Sleep latency (min) } & $\mathrm{HAB}$ & $25 \pm 4$ & $6 \pm 1^{\star \star \star}$ & 0.10 & $70.7^{\$ \$ \$}$ & 0.10 \\
\hline & EXT & $25 \pm 4$ & $6 \pm 2^{\star \star \star}$ & & & \\
\hline \multirow[t]{2}{*}{ WASO (min) } & $\mathrm{HAB}$ & $47 \pm 6$ & $27 \pm 6^{*}$ & 1.10 & $17.1^{\$ \$ \$}$ & 4.00 \\
\hline & EXT & $63 \pm 8$ & $24 \pm 4^{*}$ & & & \\
\hline
\end{tabular}

ANOVA effect: ${ }^{\$ \$} p<0.01, \$ \$ \$ p<0.001$.

N6 vs. RecN: ${ }^{\star} p<0.05,{ }^{* *} p<0.01,{ }^{* * *} p<0.001$.

HAB vs. EXT: \#p < 0.05, \#\#\#p <0.001.

WASO, Wake after sleep onset; REM, Rapid eye movement.

functions throughout the body. Intra- and extra-cellular adenosine levels rise in response to physiological stimuli and with metabolic/energetic perturbations (such as prolonged wakefulness), inflammatory challenges, and tissue injury. In the CNS, several pieces of evidence support a role for the $A_{1} R$ and $\mathrm{A}_{2 \mathrm{~A}} \mathrm{R}$ in mediating the sleep promoting actions of adenosine. In the human brain, a previous study evidenced that a single night of sleep deprivation leads to a significant increase of the $A_{1} R$ availability in cortical and subcortical brain regions (Elmenhorst et al., 2007), and there is any data on $A_{2 A} R$ at the CNS or at the peripheral level during sleep deprivation. Our study is the first showing an increase in the gene expression of $\mathrm{A}_{2 \mathrm{~A}} \mathrm{R}$ in leukocytes of healthy subjects after $24 \mathrm{~h}$ of sleep deprivation and a return to basal level after a night of recovery sleep. No change was observed in the gene expression of $A_{1} R$. Another sleep regulatory signal is initiated by extracellular ATP changes that are detected by the purinergic $\mathrm{P}_{2} \mathrm{X}_{7}$ receptors on glia, and causes in turn the release of the somnogenic TNF- $\alpha$ and
IL-1 $\beta$ pro-inflammatory cytokines (Krueger et al., 2008, 2010, 2013). Indeed, the ATP acting at $P 2 X_{7}$ receptors was initially demonstrated to serve as an efficient secondary stimulus for the generation and release of IL-1 $\beta$ from proinflammatory cells (Ferrari et al., 1997). Krueger et al. demonstrated that mice lacking the $\mathrm{P} 2 \mathrm{X}_{7}$ receptor exhibit reduced duration of non-REM sleep and reduced EEG $\delta$ wave power during non-REM sleep compared to control mice after sleep deprivation (Krueger et al., 2010). There is only one study showing increase of $\mathrm{P}_{2} \mathrm{RX}_{7}$ expression in monocytes of healthy subjects (eight participants, four males, and four females) after total sleep deprivation, and authors suggested that is a stress response to sleep deprivation (Backlund et al., 2012). In our study, we showed significant increase of $\mathrm{P}_{2} \mathrm{RX}_{7} \mathrm{mRNA}$ after the night of sleep recovery compared to $24 \mathrm{~h}-S D$, and no change IL- $1 \beta$, and TNF- $\alpha$ neither after $24 \mathrm{~h}-S D$ nor after the night of sleep recovery. This does not preclude a TNF- $\alpha$ response to TSD, as we previously revealed increased whole-blood gene expression of TNF- $\alpha$ after $25 \mathrm{~h}$ of 
TABLE 2 | Pearson rank correlation coefficients between mRNA levels of $A_{1} R, A_{2} A R$, and TNF- $\alpha$ at baseline and recovery and sleep parameters of the previous night (N6 or RecN).

\begin{tabular}{|c|c|c|c|}
\hline \multicolumn{4}{|l|}{ BASELINE } \\
\hline Stage 3 sleep latency & $\mathrm{HAB}$ & $0.703^{\star}$ & $A_{1} R$ \\
\hline \multirow[t]{5}{*}{ N6 } & EXT & 0.145 & $A_{1} R$ \\
\hline & $\mathrm{HAB}$ & -0.182 & $A_{2 A} R$ \\
\hline & EXT & $-0.650^{*}$ & $A_{2 A} R$ \\
\hline & $\mathrm{HAB}$ & -0.029 & TNF- $\alpha$ \\
\hline & EXT & $-0.720^{\star}$ & TNF- $\alpha$ \\
\hline Sleep onset latency & $\mathrm{HAB}$ & $0.612^{*}$ & $A_{1} R$ \\
\hline \multirow[t]{3}{*}{ N6 } & EXT & -0.34 & $A_{1} R$ \\
\hline & $\mathrm{HAB}$ & -0.121 & TNF- $\alpha$ \\
\hline & EXT & $-831^{*}$ & TNF- $\alpha$ \\
\hline \multicolumn{4}{|l|}{ RECOVERY } \\
\hline Stage 3 sleep latency & $\mathrm{HAB}$ & 0.295 & $A_{1} R$ \\
\hline \multirow[t]{5}{*}{$\mathrm{RecN}$} & EXT & -0.343 & $A_{1} R$ \\
\hline & $\mathrm{HAB}$ & -0.228 & $A_{2 A} R$ \\
\hline & EXT & -0.251 & $A_{2 A} R$ \\
\hline & $\mathrm{HAB}$ & -0.06 & TNF- $\alpha$ \\
\hline & EXT & $-0.571^{*}$ & TNF- $\alpha$ \\
\hline Sleep onset latency & $\mathrm{HAB}$ & 0.341 & $A_{1} R$ \\
\hline \multirow[t]{3}{*}{ REcN } & EXT & 0.389 & $A_{1} R$ \\
\hline & $\mathrm{HAB}$ & -0.124 & TNF- $\alpha$ \\
\hline & EXT & -0.37 & TNF- $\alpha$ \\
\hline
\end{tabular}

*Significant correlations $(p<0.05)$.

N6, the sixth night before the $24 \mathrm{~h}$ sleep deprivation.

RecN, the night of sleep recovery.

sleep deprivation and increased circulating levels at 34 and $37 \mathrm{~h}$ of sleep deprivation (Chennaoui et al., 2011, 2014). Also Irwin et al. have evidenced an increase of the spontaneous TNF- $\alpha$ monocytic expression after a night of sleep loss, which persisted in monocytes even after a night of recovery sleep (Irwin et al., 2006, 2015).

In the periphery, significant levels of the $A_{2 A}$ or $\mathrm{P}_{2} \mathrm{X}_{7}$ receptors expression have been evidenced in immune cells such as lymphocytes, monocytes, peripheral macrophages, neutrophils (North, 2002; Fortin et al., 2006; Fredholm et al., 2007), and it has become clear that they play critical role in the modulation of inflammatory reactions through complex mechanisms (Skaper et al., 2010; Sheth et al., 2014). Human neutrophils expressed significant amounts of $\mathrm{A}_{2 \mathrm{~A}} \mathrm{R}$ transcripts that are maximally upregulated after $4 \mathrm{~h}$ stimulation with low TNF- $\alpha$ concentration and maintained up to $21 \mathrm{~h}$ (Fortin et al., 2006). In this study, TNF- $\alpha$ also increased $A_{2 A} R$ protein expression but the kinetic of induction is different from that of $\mathrm{A}_{2 \mathrm{~A}} \mathrm{R}$ mRNA as the amounts of $\mathrm{A}_{2 \mathrm{~A}} \mathrm{R}$ protein had returned to baseline after $12 \mathrm{~h}$ of TNF$\alpha$ exposure. In line with most studies showing an increase in monocytic TNF- $\alpha$ expression during total sleep deprivation, increased expression of $\mathrm{A}_{2 \mathrm{~A}} \mathrm{R}$ in our study (additionally in positive correlation with TNF- $\alpha$ ) could be the result of low-grade inflammation and related TNF- $\alpha$ generated by the total sleep deprivation.
In our study, we determined if basal sleep duration influences $\mathrm{A}_{1} \mathrm{R}, \mathrm{A}_{2 \mathrm{~A}} \mathrm{R}$, and $\mathrm{P}_{2} \mathrm{RX}_{7}$ mRNA levels and IL-1 $\beta$ and TNF$\alpha$ during total sleep deprivation and sleep recovery, because down-regulation of $A_{1} R$ was suggested to mediate beneficial effect of sleep extension on cognitive performance during total sleep deprivation and recovery (Arnal et al., 2015). We observed higher total sleep time and higher duration time of N1, N2, and REM sleep stages in the extended basal sleep condition, but no effect on the expression of $A_{1} R$ which partially responds to our hypothesis (Arnal et al., 2015), no effect on $A_{2 A} R$, and P2RX 7 , nor on IL- $1 \beta$ and TNF- $\alpha$. However, we did not measure their circulating protein level or function nor adenosine levels which limits the responses to our hypothesis (Arnal et al., 2015) and that of Rupp et al. who suggested that changes of extracellular adenosine/adenosine receptor ratio may explain behavioral consequences of sleep restriction, recovery, and sleep extension (Rupp et al., 2009). We confirmed that expression of $\mathrm{A}_{1} \mathrm{R}$ gene is low compared $\mathrm{A}_{2 \mathrm{~A}} \mathrm{R}$ as previously highlighted in neutrophils (Fortin et al., 2006), and we can suggest thus that $\mathrm{A}_{2 \mathrm{~A}} \mathrm{R}$ expression in leukocytes could be a reliable peripheral marker of sleep deprivation in human. Our results also show high and opposite correlations between $\mathrm{A}_{1} \mathrm{R}$ and $\mathrm{A}_{2 \mathrm{~A}} \mathrm{R}$ expressions at baseline before sleep deprivation and latency of stage 3 sleep during the previous night, which give meaning to the suggestion of Sheth et al. (2014) concerning the involvement of adenosine receptors in the regulation of sleep. From their studies on mice with a global deletion in the p50 subunit of NF- $\kappa$ B, Sheth et al. (2014) speculated that the increase in cortical $A_{2 A} R$ could explain the increases in slow wave and REM sleep, in addition to their rapid recovery following sleep deprivation. In our study, TNF- $\alpha$ expression was also negatively correlated with the latency of stage 3 sleep in the EXT sleep condition, which may emphasize Krueger et al. who suggested that $\mathrm{TNF}-\alpha$ plays a role in sleep regulation and in particular enhances non-REM sleep (Krueger et al., 2008). Our results showed that high levels of stage 3 sleep latency coincided with high $\mathrm{A}_{1} \mathrm{R}(r=0.703, p<0.05)$ and low $\mathrm{A}_{2 \mathrm{~A}} \mathrm{R}$ and TNF$\alpha$ mRNA levels $(r=-0.650$, and $r=-0.720, p<0.05)$ in the EXT and HAB sleep conditions, respectively. In addition, these correlations were not significant when examined after the night of sleep recovery, which may be related to a buffering effect of the stage 3 rebound during the recovery night after TSD (Arnal et al., 2015). The correlations we observe could add information on the relationship between $A_{1} R$ and $A_{2 A} R$ and TNF- $\alpha$ gene expression and stage 3 sleep which is the sleep stage that mediates at least some of the beneficial functions of sleep on the brain, such as memory consolidation (Tononi and Cirelli, 2014). We also consider that it would be interesting to study the effects of sleep deprivation and/or sleep extension on other neurotransmitters that play wake-promoting action such as norepinephrine and serotonin in the leukocytes from healthy subjects. Indeed, monoamine's receptors are expressed by leukocytes (Chennaoui et al., 2005), and sleep deprivation has been evidenced to increase serotonergic turnover in the basal forebrain (Zant et al., 2011) and to induce alterations in the norepinephrine system in the basal forebrain and cingulate cortex (Kim et al., 2013). 
Some limitations of this study need to be noted. We focused on determination of peripheral gene expression of five biomarkers involved in the sleep regulation, but we did not include determination of their protein levels. Future studies are needed to determine whether sleep deprivationinduced changes in leukocyte gene expression are paralleled by altered protein levels. In addition, we conducted a highly controlled laboratory study with a small sample size of healthy young subjects, so future studies should be made on large healthy population or clinical cases with sleep disorders.

\section{CONCLUSION}

The presented results showed for the first time that $24 \mathrm{~h}$ of sleep deprivation increased gene expression of the $A_{2 A} R$ in leukocytes of healthy subjects and did not change $A_{1} R$, and this even if bedtime was initially increased by $1.5 \mathrm{~h}$ per night for six nights. A delayed increase of the $\mathrm{P}_{2} \mathrm{RX}_{7}$ expression after the night of sleep recovery is observed, and TNF- $\alpha$ and IL- $1 \beta$ expressions were not changed. Interestingly the latency of stage 3 sleep was positively correlated with $\mathrm{A}_{1} \mathrm{R}$ and negatively with $\mathrm{A}_{2 \mathrm{~A}} \mathrm{R}$ and TNF- $\alpha$ expression. The correlation analysis supported the hypothesis that adenosine receptors in the periphery may reflect sleep pattern in healthy subjects. Further, studies are warranted to determine if $\mathrm{A}_{2 \mathrm{~A}}$ receptor changed at the protein level and functionality.

\section{REFERENCES}

Arnal, P. J., Drogou, C., Sauvet, F., Regnauld, J., Dispersyn, G., Faraut, B., et al. (2016). Effect of sleep extension on the subsequent testosterone, cortisol and prolactin responses to total sleep deprivation and recovery. J. Neuroendocrinol. 28:12346. doi: 10.1111/jne.12346

Arnal, P. J., Sauvet, F., Leger, D., van Beers, P., Bayon, V., Bougard, C., et al. (2015). Benefits of sleep extension on sustained attention and sleep pressure before and during total sleep deprivation and recovery. Sleep 38, 1935-1943. doi: $10.5665 /$ sleep. 5244

Backlund, L., Lavebratt, C., Frisén, L., Nikamo, P., Hukic Sudic, D., TräskmanBendz, L., et al. (2012). P2RX7: expression responds to sleep deprivation and associates with rapid cycling in bipolar disorder type 1. PLoS ONE 7:e43057. doi: 10.1371/journal.pone.0043057

Basheer, R., Bauer, A., Elmenhorst, D., Ramesh, V., and McCarley, R. W. (2007). Sleep deprivation upregulates $\mathrm{A} 1$ adenosine receptors in the rat basal forebrain. Neuroreport 18, 1895-1899. doi: 10.1097/WNR.0b013e3282f262f6

Basheer, R., Strecker, R. E., Thakkar, M. M., and McCarley, R. W. (2004). Adenosine and sleep-wake regulation. Prog. Neurobiol. 73, 379-396. doi: 10.1016/j.pneurobio.2004.06.004

Beck, A. T., Ward, C. H., Mendelson, M., Mock, J., and Erbaugh, J. (1961). An inventory for measuring depression. Arch. Gen. Psychiatry 4, 561-571 doi: 10.1001/archpsyc.1961.01710120031004

Bodenmann, S., Hohoff, C., Freitag, C., Deckert, J., Rétey, J. V., Bachmann, V., et al. (2012). Polymorphisms of ADORA2A modulate psychomotor vigilance and the effects of caffeine on neurobehavioural performance and sleep EEG after sleep deprivation. Br. J. Pharmacol. 165, 1904-1913. doi: 10.1111/j.1476-5381.2011.01689.x

Buysse, D. J., Reynolds, C. F. III., Monk, T. H., Berman, S. R., and Kupfer, D. J. (1989). The pittsburgh sleep quality index: a new instrument for psychiatric practice and research. Psychiatry Res. 28, 193-113. doi: 10.1016/0165-1781(89)90047-4

Casati, M., Arosio, B., Gussago, C., Ferri, E., Magni, L., Assolari, L., et al. (2016). Down-regulation of adenosine $\mathrm{A} 1$ and $\mathrm{A} 2 \mathrm{~A}$ receptors in peripheral cells

\section{AUTHOR'S NOTE}

This work was performed in the French armed forces biomedical research institute (IRBA), Brétigny sur Orge, France.

\section{AUTHOR CONTRIBUTIONS}

Authors have made substantial contributions to the following: Conception and design of the study: MC, PA, FS, and DG. Acquisition and analysis of data: MC, PA, CD, and FS. Interpretation of data and final approval of the version to be submitted: MC, PA, CD, DL, FS, and DG. Writing the manuscript: MC, PA, DL, FS, and DG. Revisiting the manuscript: $\mathrm{MC}, \mathrm{PA}, \mathrm{DL}, \mathrm{FS}$, and DG.

\section{FUNDING}

At the IRBA (French Armed Forces Biomedical Research Institute, ministry of defense) studies are funded in operating cost by the DGA (General Directorate for Armament, ministry of defense), contracts 14Ca703 and PDH-1-SMO-2-508.

\section{ACKNOWLEDGMENTS}

We thank all personnel from IRBA and the Laboratory of Biochemistry of Val-de-Grâce Military Hospital for their technical contribution.

from idiopathic normal-pressure hydrocephalus patients. J. Neurol. Sci. 361, 196-199. doi: 10.1016/j.jns.2015.12.040

Chennaoui, M., Drogou, C., Gomez-Merino, D., and Guezennec, C. Y. (2005). Effects of an intense training on functional activity of 5-HT(1B) receptors in human peripheral blood lymphocytes. Neurosci. Lett. 382, 1-4. doi: 10.1016/j.neulet.2005.01.011

Chennaoui, M., Drogou, C., Sauvet, F., Gomez-Merino, D., Scofield, D. E., and Nindl, B. C. (2014). Effect of acute sleep deprivation and recovery on Insulinlike Growth Factor-I responses and inflammatory gene expression in healthy men. Eur. Cytokine Netw. 25, 52-57. doi: 10.1684/ecn.2014.0356

Chennaoui, M., Gomez-Merino, D., Drogou, C., Geoffroy, H., Dispersyn, G., Langrume, C., et al. (2015). Effects of exercise on brain and peripheral inflammatory biomarkers induced by total sleep deprivation in rats. J. Inflamm. 12:56. doi: 10.1186/s12950-015-0102-3

Chennaoui, M., Sauvet, F., Drogou, C., Van Beers, P., Langrume, C., Guillard, M., et al. (2011). Effect of one night of sleep loss on changes in tumor necrosis factor alpha (TNF- $\alpha$ ) levels in healthy men. Cytokine 56, 318-324. doi: 10.1016/j.cyto.2011.06.002

Chiu, G. S., and Freund, G. G. (2014). Modulation of neuroimmunity by adenosine and its receptors: metabolism to mental illness. Metab. Clin. Exp. 63, 1491-1498. doi: 10.1016/j.metabol.2014.09.003

Coleman, C. G., Baghdoyan, H. A., and Lydic, R. (2006). Dialysis delivery of an adenosine A2A agonist into the pontine reticular formation of $\mathrm{C} 57 \mathrm{BL} / 6 \mathrm{~J}$ mouse increases pontine acetylcholine release and sleep. J. Neurochem. 96, 1750-1759. doi: 10.1111/j.1471-4159.2006.03700.x

Elmenhorst, D., Basheer, R., McCarley, R. W., and Bauer, A. (2009). Sleep deprivation increases $\mathrm{A}(1)$ adenosine receptor density in the rat brain. Brain Res. 1258, 53-58. doi: 10.1016/j.brainres.2008.12.056

Elmenhorst, D., Meyer, P. T., Winz, O. H., Matusch, A., Ermert, J., Coenen, H. H., et al. (2007). Sleep deprivation increases A1 adenosine receptor binding in the human brain: a positron emission tomography study. J. Neurosci. 27, 2410-2415. doi: 10.1523/JNEUROSCI.5066-06.2007

Ferrari, D., Chiozzi, P., Falzoni, S., Dal Susino, M., Melchiorri, L., Baricordi, O. R., et al. (1997). Extracellular ATP triggers IL-1 beta release by activating 
the purinergic P2Z receptor of human macrophages. J. Immunol. 159, 1451-1458.

Fortin, A., Harbour, D., Fernandes, M., Borgeat, P., and Bourgoin, S. (2006). Differential expression of adenosine receptors in human neutrophils: upregulation by specific Th1 cytokines and lipopolysaccharide. J. Leukoc. Biol. 79, 574-585. doi: 10.1189/jlb.0505249

Fredholm, B. B., Chern, Y., Franco, R., and Sitkovsky, M. (2007). Aspects of the general biology of adenosine A2A signaling. Prog. Neurobiol. 83, 263-276. doi: 10.1016/j.pneurobio.2007.07.005

Hohoff, C., Garibotto, V., Elmenhorst, D., Baffa, A., Kroll, T., Hoffmann, A., et al. (2014). Association of adenosine receptor gene polymorphisms and in vivo adenosine A1 receptor binding in the human brain. Neuropsychopharmacology 39, 2989-2999. doi: 10.1038/npp.2014.150

Horne, J. A., and Ostberg, O. (1976). A self-assessment questionnaire to determine morningness-eveningness in human circadian rhythms. Int. J. Chronobiol. 4, 97-110.

Hurtado-Alvarado, G., Domínguez-Salazar, E., Pavon, L., Velázquez-Moctezuma, J., and Gómez-González, B. (2016). Blood-brain barrier disruption induced by chronic sleep loss: low-grade inflammation may be the link. J. Immunol. Res. 2016:4576012. doi: 10.1155/2016/4576012

Iber, C., Ancoli-Israel, S., Chesson, A. L., and Quan, S. F. (2007). The AASM Manual for the Scoring of Sleep and Associated Events: Rules, Terminology, and Technical Specifications. Westchester, IL: American Academy of Sleep Medicine.

Irwin, M. R., Wang, M., Campomayor, C. O., Collado-Hidalgo, A., and Cole, S. (2006). Sleep deprivation and activation of morning levels of cellular and genomic markers of inflammation. Arch. Intern. Med. 166, 1756-1752. doi: 10.1001/archinte.166.16.1756

Irwin, M. R., Witarama, T., Caudill, M., Olmstead, R., and Breen, E. C. (2015). Sleep loss activates cellular inflammation and signal transducer and activator of transcription (STAT) family proteins in humans. Brain Behav. Immun. 47, 86-92. doi: 10.1016/j.bbi.2014.09.017

Johns, M. W. (1961). A new method for measuring daytime sleepiness: the Epworth sleepiness scale. Sleep 14, 540-545. doi: 10.1093/sleep/14. 6.540

Kalinchuk, A. V., McCarley, R. W., Porkka-Heiskanen, T., and Basheer, R. (2011). The time course of adenosine, nitric oxide (NO) and inducible NO synthase changes in the brain with sleep loss and their role in the nonrapid eye movement sleep homeostatic cascade. J. Neurochem. 116, 260-272. doi: 10.1111/j.1471-4159.2010.07100.x

Kim, Y., Bolortuya, Y., Chen, L., Basheer, R., McCarley, R. W., and Strecker, R. E. (2012). Decoupling of sleepiness from sleep time and intensity during chronic sleep restriction: evidence for a role of the adenosine system. Sleep 35, 861-869. doi: $10.5665 /$ sleep. 1890

Kim, Y., Chen, L., McCarley, R. W., and Strecker, R. E. (2013). Sleep allostasis in chronic sleep restriction: the role of the norepinephrine system. Brain Res. 1531, 9-16. doi: 10.1016/j.brainres.2013.07.048

Kim, Y., Elmenhorst, D., Weisshaupt, A., Wedekind, F., Kroll, T., Mccarley, R. W., et al. (2015). Chronic sleep restriction induces long-lasting changes in adenosine and noradrenaline receptor density in the rat brain. J. Sleep Res. 24, 549-558. doi: 10.1111/jsr.12300

Krueger, J. M. (2008). The role of cytokines in sleep regulation. Curr. Pharm. Des. 14, 3408-3416. doi: 10.2174/138161208786549281

Krueger, J. M., Huang, Y. H., Rector, D. M., and Buysse, D. J. (2013). Sleep: a synchrony of cell activity-driven small network states. Eur. J. Neurosci. 38, 2199-2209. doi: 10.1111/ejn.12238

Krueger, J. M., Rector, D. M., Roy, S., Van Dongen, H. P., Belenky, G., and Panksepp, J. (2008). Sleep as a fundamental property of neuronal assemblies. Nat. Rev. Neurosci. 9, 910-919. doi: 10.1038/nrn2521

Krueger, J. M., Taishi, P., De, A., Davis, C. J., Winters, B. D., Clinton, J., et al. (2010). ATP and the purine type 2 X7 receptor affect sleep. J. Appl. Physiol. 109, 1318-1327. doi: 10.1152/japplphysiol.00586.2010

Krügel, U. (2016). Purinergic receptors in psychiatric disorders. Neuropharmacology 104, 212-225. doi: 10.1016/j.neuropharm.2015.10.032

Landolt, H. P., Rétey, J. V., and Adam, M. (2012). Reduced neurobehavioral impairment from sleep deprivation in older adults: contribution of adenosinergic mechanisms. Front. Neurol. 3:62. doi: 10.3389/fneur.2012. 00062
Light, A. R., Bateman, L., Jo, D., Hughen, R. W., Vanhaitsma, T. A., White, A. T., et al. (2012). Gene expression alterations at baseline and following moderate exercise in patients with chronic fatigue syndrome and fibromyalgia syndrome. J. Intern. Med. 271, 64-81. doi: 10.1111/j.1365-2796.2011.02405.x

North, R. A. (2002). Molecular physiology of P2X receptors. Physiol. Rev. 82, 1013-1067. doi: 10.1152/physrev.00015.2002

Oishi, Y., Huang, Z.-L., Fredholm, B. B., Urade, Y., and Hayaishi, O. (2008). Adenosine in the tuberomammillary nucleus inhibits the histaminergic system via $\mathrm{A} 1$ receptors and promotes non-rapid eye movement sleep. Proc. Natl. Acad. Sci. U.S.A. 105, 19992-19997. doi: 10.1073/pnas.0810926105

Porkka-Heiskanen, T., Strecker, R. E., and McCarley, R. W. (2000). Brain site-specificity of extracellular adenosine concentration changes during sleep deprivation and spontaneous sleep: an in vivo microdialysis study. Neuroscience 99, 507-517. doi: 10.1016/S0306-4522(00)00220-7

Rodrigues, R. J., Tomé, A. R., and Cunha, R. A. (2015). ATP as a multi-target danger signal in the brain. Front. Neurosci. 9:148. doi: 10.3389/fnins.2015.00148

Rupp, T. L., Wesensten, N. J., Bliese, P. D., and Balkin, T. J. (2009). Banking sleep: realization of benefits during subsequent sleep restriction and recovery. Sleep $32,311-321$.

Rupp, T. L., Wesensten, N. J., Newman, R., and Balkin, T. J. (2013). PER3 and ADORA2A polymorphisms impact neurobehavioral performance during sleep restriction. J. Sleep Res. 22, 160-165. doi: 10.1111/j.1365-2869.2012.01062.x

Sauvet, F., Drogou, C., Bougard, C., Arnal, P. J., Dispersyn, G., Bourrilhon, C., et al. (2015). Vascular response to 1 week of sleep restriction in healthy subjects. A metabolic response? Int. J. Cardiol. 190, 246-255. doi: 10.1016/j.ijcard.2015.04.119

Sheth, S., Brito, R., Mukherjea, D., Rybak, L. P., and Ramkumar, V. (2014). Adenosine receptors: expression, function and regulation. Int. J. Mol. Sci. 15, 2024-2052. doi: 10.3390/ijms15022024

Skaper, S. D., Debetto, P., and Giusti, P. (2010). The P2X7 purinergic receptor: from physiology to neurological disorders. FASEB J. 24, 337-345. doi: 10.1096/fj.09-138883

Sullivan, P. F., Fan, C., and Perou, C. M. (2006). Evaluating the comparability of gene expression in blood and brain. Am. J. Med. Genet. B Neuropsychiatr. Genet. 141B, 261-268. doi: 10.1002/ajmg.b.30272

Tononi, G., and Cirelli, C. (2014). Sleep and the price of plasticity: from synaptic and cellular homeostasis to memory consolidation and integration. Neuron 81, 12-34. doi: 10.1016/j.neuron.2013.12.025

Varani, K., Vincenzi, F., Tosi, A., Gessi, S., Casetta, I., Granieri, G., et al. (2010). A2A adenosine receptor overexpression and functionality, as well as TNFalpha levels, correlate with motor symptoms in Parkinson's disease. FASEB J. 24, 587-598. doi: 10.1096/fj.09-141044

Watson, C. J., Baghdoyan, H. A., and Lydic, R. (2010). Neuropharmacology of sleep and wakefulness. Sleep Med. Clin. 5, 513-528. doi: 10.1016/j.jsmc.2010.08.003

Weber, F., and Dan, Y. (2016). Circuit-based interrogation of sleep control. Nature 538, 51-59. doi: 10.1038/nature19773

Zant, J. C., Leenaars, C. H., Kostin, A., Van Someren, E. J., and Porkka-Heiskanen, T. (2011). Increases in extracellular serotonin and dopamine metabolite levels in the basal forebrain during sleep deprivation. Brain Res. 1399, 40-48. doi: 10.1016/j.brainres.2011.05.008

Zigmond, A. S., and Snaith, R. (1983). The hospital anxiety and depression scale. Acta Psychiatr. Scand. 67, 361-370. doi: 10.1111/j.1600-0447.1983.tb09716.x

Conflict of Interest Statement: The authors declare that the research was conducted in the absence of any commercial or financial relationships that could be construed as a potential conflict of interest.

The reviewer RG and handling Editor declared their shared affiliation, and the handling Editor states that the process nevertheless met the standards of a fair and objective review.

Copyright $\odot 2017$ Chennaoui, Arnal, Drogou, Leger, Sauvet and Gomez-Merino. This is an open-access article distributed under the terms of the Creative Commons Attribution License (CC BY). The use, distribution or reproduction in other forums is permitted, provided the original author(s) or licensor are credited and that the original publication in this journal is cited, in accordance with accepted academic practice. No use, distribution or reproduction is permitted which does not comply with these terms. 